\title{
Analysis of Influencing Factors of Electronic and Communication Equipment Manufacturing Industry from the Perspective of Innovation
}

\author{
$\mathrm{Xu}$ Chenxi \\ Management School \\ Wuhan University of Science and Technology \\ Wuhan, China \\ 2811394033@qq.com
}

\author{
Pan Kailing \\ Management School \\ Wuhan University of Science and Technology \\ Wuhan, China \\ pank10122@qq.com
}

\begin{abstract}
From the perspective of innovation ecosystem, this paper selects the development indicators that influence the hightech industries. Using the method of factor analysis, this paper structures a new state of three factors of high-tech industry innovation system including the high-tech industry innovation potential, high-tech industry flow and high-tech industry state. The study found that compared to other high-tech industries, the key to the development of electronic and communication equipment manufacturing industry is to realize efficient conversion of high-tech industry innovation, including effective output of innovative products and the investment of the innovation capital. This paper summarizes three factors affecting electronic and telecommunication equipment manufacturing industry's development. The factor lies in the way the better external support, more attention to the efficiency, the validity of innovation and transformation and market oriented production. The innovation lies in summarizing the development of the electronic and communication equipment manufacturing industry from the three dimensions of the innovation ecosystem.
\end{abstract}

Keywords-electronic and communication equipment manufacturing industry; high-tech industry; innovation factors; factor analysis

\section{INTRODUCTION}

The development of high and new technology industry not only plays an important role in stimulating the growth of national economic to a great extent but has received extensive attention from various industries. As a member of the high and new technology industry, the electronic and communication equipment manufacturing industry has been supported by the Chinese government for a long time, which is better than other high-tech industries. As of 2015, the total profit generated by the electronic and communications equipment manufacturing industry has reached 434890.97 million Yuan, far ahead of other categories of high-tech industries. Then, there are some questions we should think. How does the electronic and communication equipment manufacturing industry stand out of many high-tech industries? What are key factors it can develop better than other industries, and what countermeasures can be offered to the development of other industries? Compared with the predecessors, the paper conducts a study that compares the electronic and communication equipment manufacturing industry and other high-tech industries, covering all sectors of high-tech industries. In this paper, the development status of electronic and communication equipment manufacturing industry and other high and new technology industries is evaluated profoundly. The key factors that the electronic communication equipment manufacturing industry developed well are summed up.

\section{OVERVIEW OF MANUFACTURING OF ELECTRONIC COMMUNICATION EQUIPMENT}

\section{A. Factors affecting the manufacturing of electronic and communications equipment}

Research on innovation management by Chen Jin shows that innovation is becoming an endless research topic, which is the mainstream research direction of technological economics. On the basis of this, there are three reasons for the innovation and influence factors of electronic and communication equipment manufacturing industry from the angle of innovation. (1) The main innovation is the organization with innovative technology, innovative knowledge and other related innovative ability. Electronic and communication equipment manufacturing industry itself emphasizes innovation. It takes innovation technology as the core competitive power and transforms it into products and services enterprises. (2) The process of innovation shows the complex relationship of the economic operation mechanism, the electronic and communication equipment manufacturing industry is in such a complex relationship. Electronic and communication equipment manufacturing industry is one of the categories of the high-tech industries, the core technology of high-tech industry has the characteristics that great development difficulty, long period, difficult to break, difficult to replicate and the high efficiency of economic conversion, which determines the internal relations between subjects is in a complex network. As one of the main parts of the electronic and communication equipment manufacturing industry, it is necessary to emphasize the cooperative symbiosis between the internal and external parts of the system. (3)From the initial concept to "industry 4.0", what innovation pursues is the coordination, stability and sustainable development within the system. The electronics and communications equipment manufacturing industry is also faced with a number of risks 
and challenges while gaining good government support. Studying electronics and communication equipment manufacturing industry from an innovative perspective can reflect the impact of input, factor flow and output factors on it.

\section{B. Innovation factor system construction of electronic and communication equipment manufacturing industry}

TABLE I. HIGH-TECH INDUSTRY, INNOVATION FACTOR, INDEX SYSTEM

\begin{tabular}{|c|c|c|}
\hline $\begin{array}{c}\text { First level } \\
\text { index }\end{array}$ & Two level index & Three level index \\
\hline \multirow{8}{*}{$\begin{array}{c}\text { Innovation } \\
\text { potential }\end{array}$} & \multirow{4}{*}{ Material potential } & Number of enterprises \\
\hline & & Number of R \& D institutions \\
\hline & & Number of new product development projects \\
\hline & & $\begin{array}{c}\text { Number of projects completed and put into } \\
\text { operation }\end{array}$ \\
\hline & \multirow{4}{*}{ Fund potential } & New fixed assets \\
\hline & & Amount of investment \\
\hline & & Total profit \\
\hline & & Main business income \\
\hline \multirow{3}{*}{$\begin{array}{l}\text { Innovation } \\
\text { flow }\end{array}$} & \multirow{2}{*}{ Technology flow } & $\begin{array}{l}\text { Expenditure on the purchase of domestic technical } \\
\text { funds }\end{array}$ \\
\hline & & \begin{tabular}{|l|} 
Technology import expenditure \\
\end{tabular} \\
\hline & Fund flow & Sales revenue of new products \\
\hline \multirow{4}{*}{$\begin{array}{c}\text { Innovative } \\
\text { state }\end{array}$} & \multirow[t]{2}{*}{ Capital status } & $\begin{array}{l}\text { Internal expenditure on research and experiment } \\
\text { funds }\end{array}$ \\
\hline & & Research and experimental project funding \\
\hline & Technical state & Number of patent applications \\
\hline & Technical state & $\begin{array}{l}\text { The time equivalent of the researchers and the } \\
\text { experimenters was equivalent }\end{array}$ \\
\hline
\end{tabular}

The article get 22 indicators from "China Statistical Yearbook of science and technology", including the number of enterprises, the main business income, total profits, export delivery value, the number of research institutions and R\&D personnel or full time equivalent, $R \& D$ internal expenditures, R\&D projects and new product development projects and new product development expenditure, new product sales income, the number of patent applications and the number of invention patents, technology introduction, digestion and absorption of expenditure, buy domestic technology expenditures, technical renovation expenditures, the number of construction projects, the completion of all projects, investment, new fixed assets and R\&D project funds. The validity of these indexes was analyzed by SPSS software, 7 indexes with low validity were excluded, and the 15 remaining indexes were combined to achieve the highest validity. These 15 indicators are constructed according to the three dimensions of state, flow and potential. The index system of industry innovation impact factors is shown in Table 1 .

\section{ANALYSIS OF INFLUENCING FACTORS OF ELECTRONIC COMMUNICATION EQUIPMENT MANUFACTURING INDUSTRY}

\section{A. Factor analysis of electronic and communication equipment manufacturing}

On the basis of constructing the index system of influencing factors of innovation in industry, this paper selects the relevant data of 5 major categories of 25 high-tech industries in the "statistical yearbook of Chinese science and technology" in 2015, and making factor analysis. The analysis results are shown in table 2.

TABLE II. FACTOR EVALUATION TABLE OF HIGH AND NEW TECHNOLOGY INDUSTRY

\begin{tabular}{|c|c|c|c|c|}
\hline Industry & F1 & F2 & F3 & $\mathbf{F}$ \\
\hline \begin{tabular}{|c|} 
Electronic and \\
communication \\
equipment \\
manufacturing industry
\end{tabular} & -48384351.91 & 43603160.13 & 65669534.33 & 4902086.472 \\
\hline $\begin{array}{c}\text { Communication } \\
\text { equipment } \\
\text { manufacturing }\end{array}$ & -24127846.23 & 22463248.98 & 32041202.35 & 2454228.723 \\
\hline $\begin{array}{c}\text { Communication } \\
\text { terminal equipment } \\
\text { manufacturing }\end{array}$ & -14435319.07 & 15787002.72 & 16869552.34 & 1500905.204 \\
\hline \begin{tabular}{|c|} 
Computer office \\
equipment \\
manufacturing industry
\end{tabular} & -9474675.162 & 9418846.522 & 11969551.55 & 965344.5186 \\
\hline $\begin{array}{c}\text { Communication system } \\
\text { equipment } \\
\text { manufacturing } \\
\end{array}$ & -9692527.163 & 6676246.262 & 15171650.01 & 953323.5185 \\
\hline $\begin{array}{l}\text { Pharmaceutical } \\
\text { manufacturing }\end{array}$ & -9078079.706 & 7165564.682 & 13352328.33 & 914687.6632 \\
\hline $\begin{array}{l}\text { Electronic device } \\
\text { manufacturing }\end{array}$ & -7800108.137 & 6640445.392 & 10968625.28 & 785104.5377 \\
\hline $\begin{array}{c}\text { Computer } \\
\text { manufacturing }\end{array}$ & -7093719.519 & 7364701.559 & 8648752.98 & 725494.7186 \\
\hline $\begin{array}{l}\text { Electronic component } \\
\text { manufacturing }\end{array}$ & -5761632.756 & 4930273.52 & 8081361.18 & 581273.9049 \\
\hline $\begin{array}{l}\text { Audiovisual equipment } \\
\text { manufacturing }\end{array}$ & -5275085.86 & 5026566.58 & 6883901.643 & 536123.8768 \\
\hline $\begin{array}{c}\text { Chemical } \\
\text { manufacturing }\end{array}$ & -4850816.441 & 3873165.397 & 7092751.815 & 489724.9195 \\
\hline $\begin{array}{l}\text { Medical instrument and } \\
\text { instrument manufacture }\end{array}$ & -4292031.124 & 3115489.592 & 6578901.502 & 428481.8993 \\
\hline $\begin{array}{c}\text { Instrument } \\
\text { manufacturing }\end{array}$ & -3471083.055 & 2647506.869 & 5191609.382 & 347405.523 \\
\hline $\begin{array}{c}\text { Aerospace equipment } \\
\text { manufacturing industry }\end{array}$ & -2757621.87 & 1918345.828 & 4303279.512 & 272814.2878 \\
\hline Aircraft manufacturing & -2293525.492 & 1691319.691 & 3483268.323 & 227756.9685 \\
\hline $\begin{array}{l}\text { Proprietary Chinese } \\
\text { medicine production }\end{array}$ & -2112682.178 & 1815539.178 & 2958896.093 & 214037.3661 \\
\hline $\begin{array}{c}\text { Other electronic } \\
\text { equipment } \\
\text { manufacturing }\end{array}$ & -1924352.762 & 1646963.022 & 2696977.247 & 193677.418 \\
\hline $\begin{array}{l}\text { Integrated circuit } \\
\text { manufacturing }\end{array}$ & -1521092.514 & 973904.9947 & 2456913.835 & 149488.0634 \\
\hline $\begin{array}{c}\text { Bio pharmaceutical } \\
\text { manufacturing }\end{array}$ & -1033551.564 & 625979.7635 & 1707628.506 & 101865.9769 \\
\hline $\begin{array}{c}\text { Medical instrument } \\
\text { manufacturing }\end{array}$ & -820948.0696 & 467982.7233 & 1387292.12 & 81076.37605 \\
\hline $\begin{array}{c}\text { Manufacture of radio } \\
\text { and television } \\
\text { equipment }\end{array}$ & -736367.9425 & 545908.4205 & 1116241.874 & 73344.0939 \\
\hline $\begin{array}{l}\text { Computer parts } \\
\text { manufacturing }\end{array}$ & -517576.687 & 426261.4374 & 742632.9077 & 52079.31009 \\
\hline $\begin{array}{c}\text { Semiconductor discrete } \\
\text { device fabrication }\end{array}$ & -263112.82 & 186862.3769 & 407344.818 & 26209.50474 \\
\hline $\begin{array}{c}\text { Spacecraft } \\
\text { manufacturing }\end{array}$ & -160614.4214 & 26479.96526 & 334918.9113 & 14893.44598 \\
\hline $\begin{array}{c}\text { Manufacture of } \\
\text { electronic vacuum } \\
\text { devices }\end{array}$ & -58380.23093 & 38347.78179 & 93529.06139 & 5796.010503 \\
\hline
\end{tabular}




\section{B. Comparative evaluation of electronic and communication equipment manufacturing industry and other high-tech industries}

Compare the development of 5 major high-tech industries, from the weight coefficient, the F1 coefficient is larger, and its corresponding ranking is higher, but from the comprehensive score ranking results, $\mathrm{F} 1$ is negative, resulting in the higher the score, the lower the overall ranking. This shows that the process of innovation investment and output in high-tech industry has its own problem, which is the low efficiency of innovation transformation and the low validity. From the results of the study, the innovation potential F1 of electronic and communication equipment manufacturing industry has the lowest score. The highest score is innovation flow F2 and innovative F3.It is shown that compared to other high-tech industries, the capacity of transferring innovation support into innovative results and innovative income is high in electronic and communications equipment manufacturing industry. Based on the composite score of three innovative factors, the development of electronic and communication equipment manufacturing industry is better in comparison with other industries under the influence of these three factors. Zang Xuheng, and other research shows that the electronic and communications equipment manufacturing industry has a stronger influence, which can stimulate social production. So what are the reasons that the electronics and communications equipment manufacturing industry can realize this? In this paper, the article summarizes several factors that make the electronic and communication equipment manufacturing industry achieve better comprehensive development results:(1)From the aspect of innovation potential of high and new technology industry, it fully accesses to external support and reasonable internal support. Xiao Min and Gao Yanmei covered by industry gathering of China electronic and communication equipment manufacturing industry competitiveness shows that electronic and communication equipment manufacturing industry mainly concentrated in the eastern region of the formation of Chinese, greatly boosted the growth of the local economy, which not only benefited from government policy support, but also the result of market choice. The study feedback that electronic and telecommunication equipment manufacturing industry in the high-tech industry innovation need supports form outside, including the support from government, the construction of a relationship between the developments of the industry for the enterprise. At the same time, it also needs the internal support, including industry scale, product innovation, technology innovation, innovative talents etc. input. Similarly, the high-tech industry is the core competitiveness of a region or country,it absorbs the attention of government and all sectors of society. As long as work out the reasonable planning, it can get the support from the government and society. The key lies in reasonable internal support, dealing with the relevant $\mathrm{R} \& \mathrm{D}$ investment, innovation, personnel training, channel development and other relations, under the premise of limited resources.(2)From the aspect of innovation flow of high-tech industry, we should pay attention to the efficiency and validity of innovation transformation. The study find that the expenses for the purchase of domestic technology funds and the technology import expenditure of the electronic and communication equipment manufacturing industry are high. At the same time, sales of new products are also higher. It can be concluded that, if necessary, high-tech industries can introduce technology to reduce their $\mathrm{R} \& \mathrm{D}$ time, and enhance the efficiency of research and development of the industry. Each industry may be skilled in some aspects, and weakness in some aspects. The introduction of technology is a kind of way, which can be more suitable for the industry that can absorb technology .If the technology absorption capacity is not up to expectations, we can choose to cooperate with other industries, technology outsourcing. It is also a strategy to improve the efficiency of a innovation. Liu Wei, through the research on the convergence trend of high-tech industry technological innovation, shows that human resources are one of the significant factors contributing to its convergence. Many studies have found that, in the long run, the key lies in the reserve and cultivation of creative talents. Although the process is relatively long, the validity is relatively high.(3)From the aspect of innovation state of high-tech industry, the core lies in the market orientation. Sun Bing and Zhang Weifeng found that the market environment will have a very important stimulating effect on technological innovation through the study of the development of the electronic and communication equipment manufacturing industry. The study also found that the mismatch problem between the support for innovation and innovation output of high-tech industries. Developing the market demand in the right way is the core to improving the innovative achievements, increasing the ability of innovation output, and realizing the balance between innovation support and innovation output. After understanding the needs of the market, it can precede related industrial planning, research and development, production and other activities. The consumer is the main role in market demand. High-tech industry needs to have a clear positioning of the consumer groups. Through the investigation, we can fully understand and excavation the needs of consumers' interests, leading the consumer demand, making consumers play an important role in the economy, realizing effective production

\section{CONCLUSION}

The core point of the above research is to realize the transformation of innovation support and innovation output into effective results of high-tech industry, which is not only the pursuit of innovation results, but also the control of the innovation process. As far as innovation is concerned, the effective output of innovative products lies mainly in the process of innovation, which is reflected in the effective input of innovative capital. The key to ensure the effective output of innovative products is innovation technology, and the key to ensure the effective input of innovation capital is the timeliness of capital investment. Other high-tech industries should learn from the electronic communications equipment and manufacturing industry how to grasp the two parts of the relationship.

\section{REFERENCES}

[1] Chen Jin. Innovation management and future outlook [J]. technology and economy, G,pp.1-9.June 2013 .In Chinese 
[2] Jackson D J.What is an innovation-ecosystem?[EB/OL].(2012-1128).WWW.ercassoc.org/docs/innovate ecosystem.pdf.

[3] Liu Zhichun, Chen Xiangdong. Study on the relationship between innovation ecosystem and innovation efficiency in Science Park [J]. research management, pp,26-31. February 2015.In Chinese

[4] Zang $\mathrm{Xu}$ identity. Industrial economics. Economic Science Press, 2015.In Chinese

[5] Cover Xiao Min, Gao Yanmei. Industry agglomeration and agglomeration transfer. Competitiveness of China's electronic and communication equipment manufacturing industry [J]. reform, pp.113212 December 2013.In Chinese

[6] Liu Wei, Chen Jingquan, Li Xingxing. TFP calculation and convergence trend of technological innovation in China's provincial high-tech industries [J]. Economic theory and economic management, pp.36-50.R. January 2013.In Chinese

[7] Sun Bing, Zhang Weifeng. [J]. study on the relationship between nonlinear statistics and decision between technology innovation and innovation environment ,pp.171-174, June 2013.In Chinese 